Joanna Kic-Drgas

Uniwersytet im. Adama Mickiewicza w Poznaniu joanna.kic-drgas@tu.koszalin.pl

\title{
SPOTKANIA MIĘDZYKULTUROWE Z PERSPEKTYWY ORGANIZATORA - CIENIE I BLASKI
}

\author{
Intercultural meetings from the organisers' perspective: \\ pros and cons
}

\begin{abstract}
Intercultural meetings are present in foreign language teaching and they are currently gaining popularity. It is the result not only of globalisation but also of the increasing sensitivity and awareness of the coexistence of different cultures. The advantages of intercultural meetings have been appreciated by teachers and tutors working with different age groups. Leaving aside their benefits, they constitute an enormous organisational challenge at the same time. The following paper aims at discussing the opportunities and potential difficulties related to intercultural challenges based on the survey conducted among Polish and German teachers organising intercultural exchanges.
\end{abstract}

Keywords: exchange, intercultural meetings, foreign language teachers, tutors

Słowa kluczowe: wymiany, spotkania interkulturowe, nauczyciele języków obcych, trenerzy

\section{Wstęp}

Spotkania kultur nie są zjawiskiem nowym i o ile na przestrzeni lat zmieniła się ich forma (początkowo miały charakter m.in. wymiany handlowej, z czasem stały się okazją do wymiany intelektualnej), to ich główny cel nie uległ zmianie, a jest nim poznanie nowego, nieznanego świata kryjącego się pod postacią kultury -innej od własnej. Początkowo spotkania międzykulturowe dotyczyły tylko wybranych osób, dziś są dostępne dla szerokiego grona zainteresowanych, a 
ich rozpowszechnieniu sprzyja także różnorodność podejmowanej tematyki, której jedynym ogranicznikiem staje się wyobraźnia organizatorów. Korzyści z przeprowadzania spotkań międzykulturowych zdają się być dla ich uczestników oczywiste, niemniej warto przyjrzeć się wymianom z perspektywy osób odpowiedzialnych za ich organizację. Organizatorzy wymian odgrywają kluczową rolę w procesie uczenia się osób biorących w nich udział, są przewodnikami w niejednokrotnie pierwszym zetknięciu z obcą kulturą, pomagają w odkrywaniu mocnych i słabych stron oraz w kształtowaniu tożsamości narodowej.

Niniejszy artykuł ma na celu zaprezentowanie trudności oraz szans związanych z organizacją i przeprowadzaniem spotkań międzykulturowych. Pierwsza część artykułu jest poświęcona próbie zdefiniowania spotkań międzykulturowych oraz ich roli w kształceniu językowym. Punktem wyjścia do tych rozważań będzie model poznawczy Kraigera, Forda i Salasa (1993) oraz jego analiza w kontekście spotkań międzykulturowych. W drugiej części rozważania teoretyczne zostaną poparte analizą wyników ankiety przeprowadzonej wśród organizatorów spotkań, aby w części ostatniej sformułować wnioski stanowiące rodzaj wskazówek dla osób zajmujących się wymianą, a także prognoz dalszego rozwoju tematyki wymian w Polsce.

\section{Spotkania międzykulturowe}

Pabian (2015: 21) definiuje spotkania międzykulturowe jako spotkania, do których dochodzi „w sytuacji, gdy osoby pochodzące z różnych kultur nawiązują kontakt bez zamiaru włączenia się w jedną z nich". Mikułowski Pomorski (2006: 120) dodaje, że jest to „zetknięcie się ludzi wychowywanych w odmiennych kulturach". Spotkania międzykulturowe mają charakter wieloaspektowy i można je realizować w bardzo różnych kontekstach tematycznych, a także w odniesieniu do różnych wartości, celów i motywów (por. Rohrscheidt, 2010: 66). Różnorodność podejmowanej tematyki wraz z wielością metod pozwala na różnorodne formy ich realizacji, do których należą:

- tradycyjne wymiany szkolne i pozaszkolne;

- projekty e-Twinningowe;

- projekty międzyuczelniane (np. projekt Powstanie Warszawskie realizowany na ILS UAM albo projekt E-Tandem między Uniwersytetem im. Adama Mickiewicza a Uniwersytetem Technicznym w Darmstadt ${ }^{1}$ ) i tworzenie wspólnych kierunków studiów (takie studia proponuje m.in. Uniwersytet Warszawski na kierunku polsko-niemieckie studia transkulturowe ${ }^{2}$ );

\footnotetext{
${ }^{1}$ Więcej na: http://ils.amu.edu.pl/index.php/pl/komponent/kontent/article/8-pl/121 -e-tandem [DW 12.10.2015].

${ }^{2}$ Więcej na: http://germanistyka.uw.edu.pl/?page_id=411 [DW 12.10.2015].
} 
- spotkania realizowane $w$ formie edukacji nieformalnej, np. Program Komisji Europejskiej - Młodzież w Działaniu;

- festiwale;

- wystawy;

- koncerty.

Na potrzeby niniejszego artykułu zostanie omówiona jedna z powyższych form - wymiana, która według Mihułki (2013: 61) należy do bezpośrednich spotkań międzykulturowych.

\section{Model poznawczy Kraigera, Forda i Salasa (1993)}

Według modelu poznawczego opisanego przez Kraigera, Forda i Salasa (1993: 311) na efektywny proces uczenia się wpływ mają następujące czynniki:

- wiedza (ang. cognitive outcomes), czyli wiadomości, które uczący zna i które stają się podstawą do zrozumienia i przyswojenia nowych zagadnień lub też są to zupełnie nowe treści, poznawane dopiero w procesie uczenia się;

- umiejętności (ang. skill-based outcomes) mają charakter praktyczny, czyli umożliwiają zastosowanie pozyskanej wiedzy w praktyce. Umiejętności są nabywane w wyniku wielokrotnego powtarzania pewnych zagadnień, co pozwala na automatyczne przywołanie określonej reakcji. Bardzo wyraźnie można to zauważyć na przykładzie języka obcego, w którym uczący się z upływem czasu nabywają płynność (automatyzują użycie), polegającą na tym, że nie zastanawiają się już nad wyborem danej konstrukcji gramatycznej czy zastosowaniem danego słowa. Kraiger, Ford i Salas (1993: 312) wymieniają następujące etapy nabywania określonych umiejętności: kompilacja, proceduralizacja, kompozycja i automatyzacja;

- postawy (ang. affective outcomes) mają charakter ściśle zindywidualizowany i określają podejście każdego uczącego się do danego obszaru wiedzy, jego motywację, chęć i skuteczność autoewaluacji czy refleksję procesu uczenia się.

Wszystkie trzy elementy opisane powyżej są równie istotne zarówno w poznawaniu świata po raz pierwszy przez małe dziecko, jak i w przypadku osoby dorosłej, która tę wiedzę o świecie jedynie w pewien sposób uzupełnia. Interesujące jest również spostrzeżenie Jeżowskiego (2013: 120), że owe elementy w kontekście uczenia się języków obcych są nie tylko równorzędne, ale mogą istnieć niezależnie od siebie: „Możemy przecież znać setki angielskich słówek i zasady gramatyki (wiedza), lecz nie umieć porozumiewać się płynnie po angielsku z powodu braku praktyki (umiejętność). Z drugiej strony, możemy mówić świetnie po francusku (umiejętność), lecz nie umieć wytłumaczyć zasad 
francuskiej zgodności czasów czy mowy zależnej (wiedza), co często można obserwować u rodzimych użytkowników języka" (Jeżowski, 2013: 120).

Jeśli wszystkie trzy elementy zaprezentowanego modelu są istotne i niezbędne do skutecznego osiągnięcia celu, jakim jest przyswojenie wiedzy językowej przełożonej na praktykę, która skłania do głębszej autorefleksji i autoewaluacji, niezbędna jest ustawiczna praca nad nimi, także na zajęciach z języka obcego. Jeśli nad pierwszym elementem na zajęciach z języka obcego w warunkach sformalizowanych można pracować bezdyskusyjnie, często ogranicza się możliwości intensywnego rozwoju umiejętności językowych czy nie poświęca się wystarczająco dużo czasu na uwrażliwienie uczących się na rolę autoewaluacji w procesie uczenia się. Warto zatem zadać sobie pytanie, w jaki sposób poszerzyć umiejętności poznawcze i zapewnić nie tylko praktyczne zastosowanie zdobytej na zajęciach językowych wiedzy, ale także zwiększyć motywację uczących się i nauczających, pokazać realne potrzeby używania języka obcego.

\section{Spotkania międzykulturowe a model poznawczy Kraigera, Forda i Salasa (1993)}

Jendrych i Wiśniewska ${ }^{3}$ podkreślają, że główną potrzebą osób uczących się w różnym wieku jest opanowanie języka obcego w warunkach postępującej globalizacji, rozumianej jako zderzenie się z kwestiami społecznymi, gospodarczymi, kulturowymi, politycznymi i ekologicznymi na pograniczu kultur. W świetle tych słów globalne podejście do znajomości języka obcego powinno znaleźć odzwierciedlenie w odpowiednio postawionych celach w jego nauczaniu.

Słusznie wiedzę w kontekście językowym definiuje Grucza (1997: 14-18), wskazując na istnienie wiedzy semantycznej i pragmatycznej, przy czym wiedza semantyczna „styka się bezpośrednio, krzyżuje, w pewnej mierze pokrywa z wiedzą o świecie”, natomiast wiedza pragmatyczna jest „ściśle powiązana z wiedzą kulturową". Okazuje się zatem, że „nie ma wyraźnej granicy oddzielającej obszar wiedzy językowej od niejęzykowej wiedzy o świecie" (Grucza, 2005: 47).

Spotkania międzykulturowe są źródłem wiedzy o otaczającym świecie, o języku pojmowanym w kontekście globalnym (zgodnie z definicją Jendrych i Wiśniewskiej), ale także, jak podkreśla Knapp (2006: 111), o własnej kulturze: „Damit sind Menschen sich ihrer Kultur häufig nicht bewusst: da sie als das "Normale« angesehen wird, zu dem einem Individuum oft keine Alternativen präsent sind“.

Ważnym aspektem spotkań międzykulturowych jest poznanie kraju partnera (bądź partnerów) z nowej perspektywy, innej niż ta przedstawiana w

3 Http://conference.pixelonline.net/ICT4LL2010/common/download/Proceedings_pdf/ CLIL01-Jendrych,Wisniewska.pdf [DW 12.08.2015]. 
podręcznikach szkolnych, w której funkcjonują osoby reprezentujące daną obcą kulturę. Każde spotkanie przyczynia się do poszerzenia wiedzy związanej z postrzeganiem otaczającej rzeczywistości i kraju partnera. Grzybowski (2011: 8) podsumowuje, że „spotkania Innych i Obcych są nie tylko możliwe, ale wręcz niezbędne do świadomego kształtowania bogatej tożsamości i dobrego samopoczucia w różnych środowiskach", a dalej wskazuje na problematyczne obszary wiedzy będące przedmiotem spotkań międzykulturowych:

- występowanie wyraźnie wyodrębniających się grup kulturowych;

- pogranicze kulturowe w kontekście wielokulturowości (jego charakter, zasięg, problemy, perspektywy, w ujęciu narodowym i międzynarodowym);

- tożsamość (kulturowa, etniczna i międzykulturowa), jej kształtowanie się, osobowości, różnice osób żyjących na pograniczach;

- postawy, stereotypy, uprzedzenia, napięcia, konflikty;

- sytuacja imigrantów, ich dzieci oraz społeczeństw pozostających w relacjach z nimi;

- polityka społeczna i oświatowa różnych podmiotów wobec innych kultur;

- skutki geograficzne i gospodarcze przemieszczania się osób z jednego środowiska kulturowego (Grzybowski, 2011: 21).

Spotkania interkulturowe poszerzają także wiedzę nauczycieli o ich podopiecznych, o tym, jak zachowują się w grupie, w sytuacjach nowych, w autentycznym spotkaniu z dotychczas nieznaną kulturą. Cenna jest także wiedza, jaką z zajęć językowych uczniowie przenoszą na grunt autentycznej komunikacji.

W kontekście drugiego elementu poznawczego opisywanego przez Kraigera, Forda i Salasa (1993) można dostrzec przewagę spotkań międzykulturowych nad nauczaniem sformalizowanym. Każde osobiste spotkanie z reprezentantem innej kultury staje się naturalną możliwością do wykorzystania w praktyce wiedzy językowej. Jeżowski i Urbaś (2013: 30) podkreślają zalety spotkań międzykulturowych w tym względzie, informując, że „,85 proc. ankietowanych twierdzi, że dzięki uczestnictwu w projekcie w ramach programu »Młodzież w działaniu « lepiej potrafi się komunikować w języku obcym".

Umiejętności analizowane w kontekście spotkań międzykulturowych to także informacja, jak działać w kontakcie z osobą reprezentującą inną kulturę. Są to umiejętności, które pozwalają odnaleźć się w zróżnicowanym środowisku, dążyć do wzajemnego zbliżenia, wytwarzając nową jakość w obopólnych stosunkach (por. Czerniejewska, 2008: 26-27).

Wreszcie spotkania międzykulturowe przyczyniają się do kształtowania postaw tolerancji i zrozumienia dla inności, a także zwiększenia motywacji do nauki języka obcego. 
Zetknięcie się z obcą kulturą pomaga w odkrywaniu swoich mocnych i słabych stron oraz w kształtowaniu własnej tożsamości narodowej, co potwierdzają następujące słowa: „Kontakt z innymi kulturami prowadzi w efekcie do lepszego poznania siebie i rozwoju osobistego. Aby to jednak mogło nastąpić, konieczne jest zapewnienie młodym ludziom warunków do bezpiecznego i efektywnego uczenia się od siebie nawzajem i czerpania z własnej różnorodności" (FRSE, 2008: 10).

\section{Przebieg badania}

W badaniu udział wzięło 27 organizatorów spotkań międzykulturowych, w tym 18 osób z Polski i 9 osób z Niemiec, reprezentujących różne szczeble edukacyjne. Przeprowadzenie ankiet było możliwe podczas seminarium metodycznego zorganizowanego przez szkołę Dialog Anna Malinowski w Karpaczu. Badanie miało na celu zebranie informacji na temat potencjalnych szans i problemów związanych z organizacją i przeprowadzaniem wymian.

\section{1. lle razy organizował/a Pan/i wymianę?}

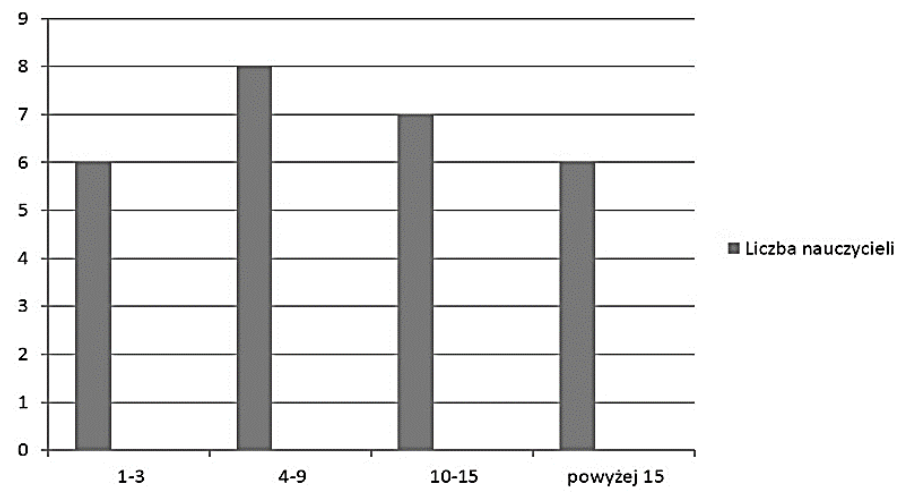

Wykres 1: Liczba organizowanych wymian.

Warto zauważyć, że zdecydowana większość uczestników badania wielokrotnie organizowała już spotkania międzykulturowe, jedna z osób nawet 30 razy. Jest to cenna informacja, gdyż uczestnicy badania zebrali duże doświadczenie w organizacji tego typu spotkań.

\subsection{W jaki sposób znalazł/a Pan/i partnera do wymiany?}

Analizując wynik badania, można zauważyć wyraźną tendencję do korzystania z prywatnych kontaktów w celu znalezienia partnera do wymiany. Bardzo pomocne 
okazały się także seminaria kontaktowe. Trzy osoby znalazły instytucję partnerską w wyniku własnych poszukiwań w Internecie, pięć osób - w mieście partnerskim; w trzech przypadkach kontakt został nawiązany ze strony instytucji partnerskiej.

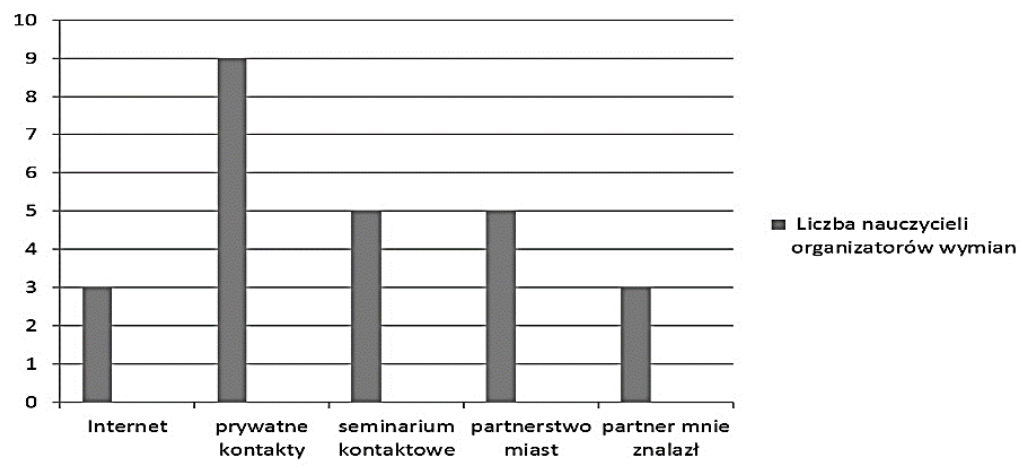

Wykres 2: Sposób znalezienia partnera do wymiany.

\subsection{Czy jest Pan/i zadowolony/a z przeprowadzonej wymiany?}

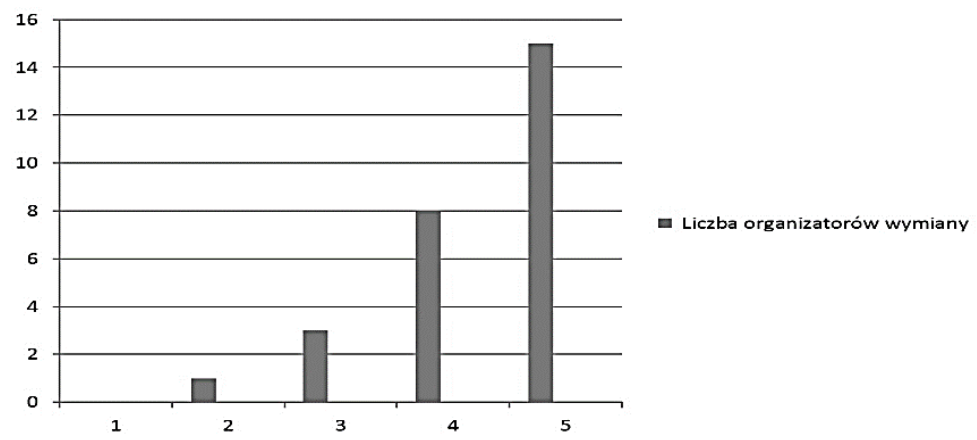

Wykres 3: Zadowolenie z przeprowadzonej wymiany (1 - nie jestem, 5-jestem bardzo).

Uzyskane wyniki świadczą o zadowoleniu z przeprowadzonych spotkań (tylko 1 osoba określiła poziom zadowolenia na 2).

\subsection{Co było najtrudniejsze w organizacji wymiany?}

Największą trudność w organizacji spotkania stanowiło zebranie funduszy ${ }^{4}$ (16 odpowiedzi) oraz wybranie odpowiednich uczestników (13 odpowiedzi). Pozostałe wymienione przez uczestników badania trudności to np.: brak pomocy ze

\footnotetext{
${ }^{4}$ W większości przypadków wymiany są finansowane ze źródeł zewnętrznych; takie dofinansowanie można uzyskać m.in. w Polsko-Niemieckiej Współpracy Młodzieży, DAAD.
} 
strony innych nauczycieli, bariera językowa (w szkołach o profilu zawodowym wymianę organizują m.in. nauczyciele zawodu, którzy nie zawsze znają język obcy), pokonanie stereotypów czy przekonanie do wymiany dyrekcji i bezpośrednich zwierzchników. Kilku osobom trudności przysporzyło ustalenie programu spotkania z partnerem oraz zorganizowanie noclegów.

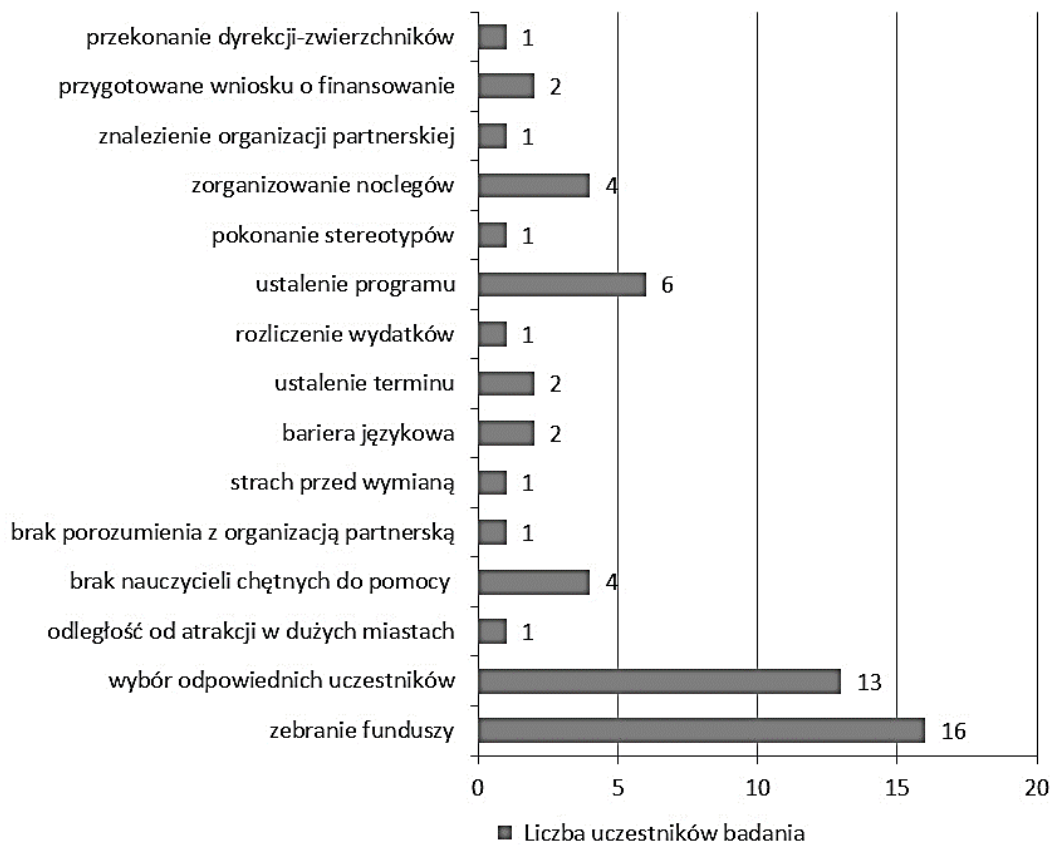

Wykres 4: Trudności w organizacji wymiany.

\subsection{Co było najtrudniejsze w przeprowadzeniu wymiany?}

Największym problemem dla organizatorów w trakcie przeprowadzania wymiany okazał się brak zaangażowania ze strony innych nauczycieli, osób zatrudnionych $w$ danej instytucji niezwiązanych bezpośrednio z wymianą ( 8 osób), ze strony uczestników wymiany (8 osób) oraz ze strony instytucji partnerskiej (1 osoba). Na etapie przeprowadzania spotkania dla 3 osób utrudnieniem była niesprzyjająca pogoda, dla 6 - napięty harmonogram. Problemy pojawiły się także u rodzin goszczących ( 5 odpowiedzi) oraz $\mathrm{w}$ związku z różnymi nawykami żywieniowymi uczestników (6 odpowiedzi) i zainteresowaniami uczestników (5 odpowiedzi). 


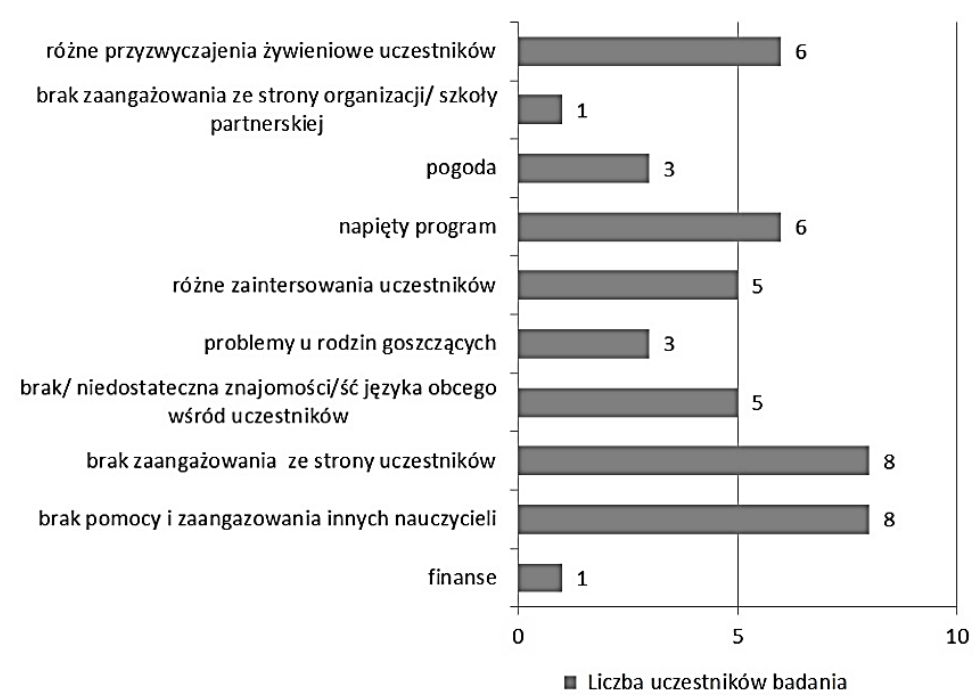

Wykres 5: Trudności w przeprowadzeniu wymiany.

\subsection{Czy jest coś, co się nie udało w przeprowadzonej wymianie? Jeśli tak, co to jest?}

Uczestnicy badania w większości ( 23 osoby) wskazali, że wymiana przebiegła bez trudności ani nieoczekiwanych zdarzeń. Pozostali uczestnicy wymienili następujące czynniki:

- czas (organizacja czasowa założonych elementów programu);

- zapewnienie adekwatnych tłumaczeń;

- zbyt mało czasu na refleksję.

Jedna osoba zauważyła: „Zawsze są jakieś problemy, ale można je rozwiązać” (Ankieta 11).

\subsection{Proszę podać trzynajważniejsze korzyści wynikające z przeprowadzonej wymiany.}

Najczęściej wymienianymi korzyściami wynikającymi z wymiany są:

- poznanie innej kultury (15 osób);

- zawarcie przyjaźni (11 osób);

- przełamanie barier i stereotypów (7 osób);

- zwiększenie motywacji do nauki języka obcego (6 osób);

- rozwijanie kompetencji komunikacyjnej w języku obcym (5 osób). Jeden z uczestników wskazał na rozwój osobisty, czterech - na uatrakcyjnienie oferty edukacyjnej, natomiast dwóch na lepsze poznanie własnych uczniów. 


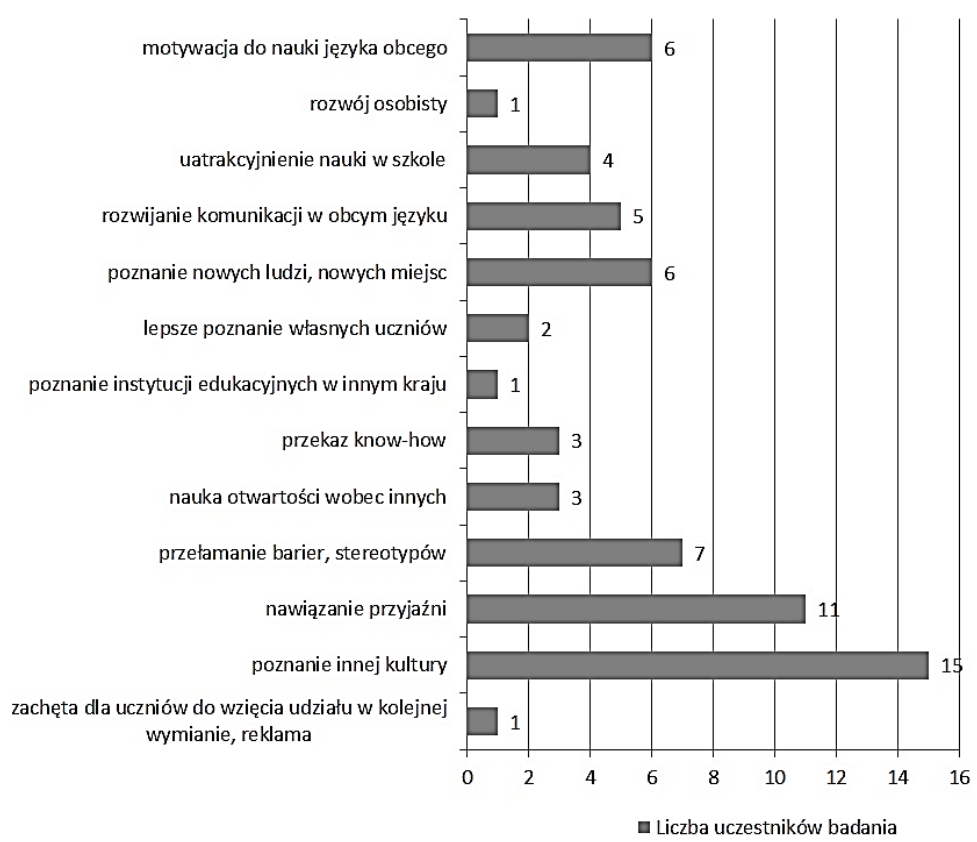

Wykres 6: Korzyści wynikające z wymiany.

\subsection{Co Panu/i wymiana dała osobiście?}

Uczestnicy badania najczęściej wskazywali na satysfakcję, którą zapewnia zorganizowanie wymiany (8 osób), możliwość poznania nowych przyjaciół (8 osób), poznanie pracy nauczyciela w innym kraju ( 2 osoby), poszerzenie wiedzy (5 osób), wymiana doświadczeń ( 5 osób) i podniesienie kompetencji językowych (4 osoby).

Warto zacytować kilka wypowiedzi:

- „Viel gelernt, rechtzeitig Pausen zu machen und Programm B immer hinter der Hand zu haben" (A 2).

- „Przede wszystkim rozwój osobisty i językowy, poznanie metod pracy stosowanych przez stronę partnerską" (A 10).

- „Wymiana przysporzyła mi stres i problemy zdrowotne” (A 5, niemniej uczestnik badania wskazuje w kolejnym punkcie na chęć kontynuowania współpracy, ale z innym partnerem).

- „Spełnienie na wszystkich płaszczyznach: zawodowej, rodzinnej i towarzyskiej (A 4)".

- "Poznałam moich uczniów od innej strony” (A 8).

- „Wyższy dodatek motywacyjny” (A 9). 


\subsection{Czy planuje Pan/i kontynuację wymiany?}

25 osób zdecydowanie zadeklarowało chęć kontynuacji organizacji wymian, jedna osoba oświadczyła, ze nie będzie już brać udziału w wymianach jako organizator, jedna wyraziła chęć współpracy, ale z innym partnerem.

\section{Wnioski}

Spotkania międzykulturowe stanowią ważny element edukacji językowej. Jak wynika z przeprowadzonego badania, przyczyniają się do odczuwania dużej satysfakcji i wzbudzają chęć ich kontynuacji wśród osób je organizujących. Zalety wymian jako jednego z typów spotkań międzykulturowych są silnie podkreślane przez organizatorów, a wśród nich w szczególności:

- w zakresie wiedzy:

- poznanie realiów życia w innym kraju;

- poznanie sposobu funkcjonowania instytucji oświatowych (i nie tylko) w kraju partnera;

○ poznanie kultury kraju partnerskiego;

○ poznanie nowych osób i miejsc;

- w zakresie umiejętności:

- rozwijanie kompetencji komunikacyjnej;

○ możliwość posługiwania się językiem w kontekście innym niż zajęcia;

- w zakresie postaw:

- przełamanie stereotypów i strachu;

- większa otwartość na drugiego człowieka;

○ zwiększenie motywacji do uczenia się języka obcego.

Wypowiedzi uczestników badania wskazują na olbrzymi potencjał poznawczy kryjący się w spotkaniach międzykulturowych. Jedocześnie badanie wykazało, że organizacja spotkań ma także drugą stronę związaną z pozyskaniem środków finansowych, ustaleniem planu, znalezieniem właściwego terminu spotkania czy brakującym zaangażowaniem ze strony uczestników. Badanie wskazało na podkreślane przez niektórych nauczycieli trudności komunikacyjne, trudności związane z niesprzyjającą atmosferą czy ze znalezieniem właściwych partnerów do wymiany.

Ważnym elementem badania było nawiązanie do osobistych korzyści wynikających z wymian, wśród których nauczyciele wymieniali satysfakcję z dobrze przeprowadzonego wydarzenia, a także radość wynikającą z poznania własnych podopiecznych z zupełnie nowej perspektywy oraz zwiększenie ich 
motywacji do nauki języka obcego. Zaprezentowane badanie nie wyczerpuje podjętego tematu; może służyć za wstęp do dalszych badań w tym obszarze, które z pewnością są nie tylko ważne, ale także potrzebne.

\section{BIBLIOGRAFIA}

Burszta, W. J. 1998. Antropologia kultury. Poznań: Zysk i S-ka.

Czerniejewska, I. 2008. Edukacja wielokulturowa. Działania podejmowane w Polsce. Toruń: Wydawnictwo Naukowe Uniwersytetu im. Mikołaja Kopernika.

FRSE. 2008. Pakiet edukacyjny Pozaformalnej Akademii Jakości Projektu. Edukacja międzykulturowa. Część 2. [online: http://erasmusplus.org.pl/wp-content/uploads/ 2014/02/pajp_ii_edukacja_miedzykulturowa.pdf; DW 12.08.2015].

Forner, W. i S. Habscheid (red.). 2006. Sprachliche und fachliche Kompetenzen: Zwei Seiten eines Blattes? Frankfurt am Main: Peter Lang.

Gesteland, R. R. 1999. Różnice kulturowe a zachowania w biznesie. Marketing, negocjacje i zarzqdzanie $w$ różnych kulturach. Warszawa: PWN.

Grucza, F. 1997: „Języki ludzkie a wyrażenia językowe, wiedza informacyjna, mózg a umysł ludzki". (w) Podejścia kognitywne w lingwistyce, translatoryce i glottodydaktyce. (red. F. Grucza i M. Dakowska). Warszawa: Wydawnictwo Uniwersytetu Warszawskiego, str. 7- 21.

Grucza, F. 2005: „Wyrażenie 'upowszechnianie nauki' - jego status i znaczenie w świetle teorii aktów komunikacyjnych i lingwistyki tekstów". (w) Teoria i praktyka upowszechniania nauki wczoraj i jutro. (red. F. Grucza i W. Wiśniewski). Warszawa: Polska Akademia Nauk, str. 41-79.

Grucza, F. i M. Dakowska (red.). 1997. Podejścia kognitywne w lingwistyce, translatoryce i glottodydaktyce. Warszawa: Wydawnictwo Uniwersytetu Warszawskiego.

Grzybowski, P. 2011. Edukacja międzykulturowa - konteksty. Od tożsamości po język międzynarodowy. Kraków: Impuls.

Hall, E. T. 1978. Ukryty wymiar. Warszawa: Państwowy Instytut Wydawniczy.

Hofstede, G., Hofstede, G. J., i M. Minkov. 2011. Kultury i organizacje. Zaprogramowanie umysłu. Warszawa: PWE.

Jeżowski, M. W. 2013. „Języki obce nie tylko w szkole!”. Języki Obce w Szkole, 4: 120-123.

Jeżowski, M. i S. Urbaś. 2013. Analiza badawcza programu „Młodzież w działaniu” (RAY). Raport ze specjalnego badania. Warszawa: Fundacja Rozwoju Systemu Edukacji.

Knapp, A. 2006: „Interkulturelle Kompetenz als »Schlüsselqualifikation« - lern- und lehrbar?“. (w) Sprachliche und fachliche Kompetenzen: Zwei Seiten eines Blattes? (red. W. Forner, S. Habscheid). Frankfurt am Main: Peter Lang, str. 105-130.

Kraiger, K., Ford, K. J. i E. Salas. 1993. „Application of Cognitive, Skill-Based, and Affective Theories of Learning Outcomes to New Methods of Training Evaluation". Journal of Applied Psychology, 78: 311-328.

Mihułka, K. 2013. „Spotkania interkulturowe z perspektywy uczenia się i nauczania języka obcego". Języki Obce w Szkole, 2: 106-117. 
Mikułowski Pomorski, J. 2006. Jak narody porozumiewajq się ze sobq w komunikacji międzykulturowej i komunikowaniu medialnym. Kraków: UNIVERSITAS.

Pabian, B. 2013. Wprowadzenie do wiedzy o kulturze. Podręcznik dla studentów kierunków turystycznych i ekonomicznych. Katowice: Wydawnictwo Uniwersytetu Ekonomicznego.

Pabian, B. 2014: „Różnice kulturowe między narodami - stymulator czy bariera świadczenia profesjonalnych usług na rynkach turystycznych?". (w) Usługi profesjonalne w globalnej gospodarce. (red. J. Matysiewicz). Warszawa: Wydawnictwo PLACET, str. 127-144.

Pabian, B. 2015. „Spotkanie międzykulturowe w kontekście turystycznego doświadczania świata. Przykład Singapuru". Turystyka Kulturowa, 2: 20-35.

Paleczny, T. 2005. Stosunki międzykulturowe. Zarys problematyki. Kraków: Krakowskie Towarzystwo Edukacyjne.

Tropeenaars, F. i C. Hampden-Turner. 2002. Siedem wymiarów kultury. Znaczenie różnic kulturowych w działalności gospodarczej. Kraków: Oficyna Ekonomiczna.

Rohrscheidt, A. M. v. 2010. Turystyka kulturowa. Fenomen, potencjał, perspektywy. Poznań: Wydawnictwo KulTour.

\section{Netografia}

http://conference.pixelonline.net/ICT4LL2010/common/download/Proceedings_pdf/C LIL01-Jendrych,Wisniewska.pdf [DW 15.08.2015]. 


\section{Aneks: ankieta}

1. Ile razy organizował/a już Pan/Pani wymianę?

2. W jaki sposób znalazł/a Pan/Pani partnera do wymiany?

3. Czy jest Pan/Pani zadowolony/zadowolona z przeprowadzonej wymiany? (1 - nie jestem, 5 - jestem bardzo)

$\begin{array}{lllll}1 & 2 & 3 & 4 & 5\end{array}$

4. Co było najtrudniejsze $\underline{w}$ organizacji wymiany? (Proszę podać 3 najważniejsze trudności).

5. Co było najtrudniejsze podczas przeprowadzania wymiany? (Proszę podać 3 najważniejsze trudności).

6. Czy jest coś, co się nie udało w przeprowadzonej wymianie? Jeśli tak, co to jest?

7. Proszę podać 3 najważniejsze korzyści wynikające z przeprowadzonej wymiany.

8. Co Panu/Pani wymiana dała osobiście?

9. Czy planuje Pan/Pani kontynuację wymiany?

- TAK

○ NIE 